\title{
Effect of Credit Risk on Financial Performance of Commercial Banks Kenya
}

\author{
Jane GathigiaMuriithi $^{1}$, Kennedy MunyuaWaweru ${ }^{2}$, Willy Mwangi Muturi ${ }^{3}$ \\ ${ }^{1,3}$ School of Business, Jomo Kenyatta University of Agriculture and Technology, Department of Economic, \\ Accounting and Finance, P.O. Box 62000-00200, Nairobi. \\ ${ }^{2}$ Department of Finance and Accounting, Co-operative University College of Kenya, P. O. Box 24814-00502 \\ Karen-Kenya Nairobi
}

\begin{abstract}
The objective of study was to assess the effect of credit risk on financial performance of commercial banks in Kenya. The study covered the period between year 2005 and 2014. Credit risk was measured by measured by capital to risk weighted assets, asset quality, loan loss provision, loan and advance ratios and financial performance by return on equity (ROE). The study used the balance sheets components and financial ratios for 43 commercial banks in Kenyaregistered by year 2014. Panel data techniques of fixed effects estimation and generalized method of moments $(G M M)$ were used to purge time-invariant unobserved firm specific effects and to mitigate potential endogeneity problems. The pairwise correlations between the variables were carried out. F- test was used to determine the significance of the regression while the coefficient of determination, within and between $R^{2}$, were used to determine how much variation in dependent variable is explained by independent variables. From the results credit risk has a negative and significant relationship with bank profitability. Poor asset quality or high non-performing loans to total asset is related to poor bank performance both in short run and long run. Based on the study findings, it is recommended that management of commercial banks in Kenya should enhance their capacity in credit analysis and loan administration.Clear credit policies and lending guidelines should be established.
\end{abstract}

Keywords: Credit Risk, financial performance, Commercial Banks, Asset quality, Loans and advances, Kenya.

\section{Introduction}

Kenyan banks are inevitably exposed to credit risk because they grant credit facilities as they accept the deposits. Credit risk is the possibility of losing the outstanding loan partially or totally, due to credit events (default risk) (BCBS, 2001). Credit risk is the exposure faced by banks when a borrower (customer) defaults in honouring debt obligations on due date or at maturity (Coyle, 2000). Kargi (2011) indicated that credit creation is the main income generating activity for the banks. As a result adequate management on loan processing is critical for the growth and survival of the banks otherwise the credit activity may lead to financial distress.CBK supervision annual report 2013 indicated that the ratio of non-performing loans to gross loans increased from 4.7 percent in December 2012 to 5.2 percent in December 2013. Later the ratio increased from 5.2 per cent in December 2013 to 5.6 per cent in December 2014 and CBK was monitoring closely institutions that were experiencing deteriorating asset quality. The report also indicated that there was also a decrease in sector's capital adequacy, which is measured by the ratio of total capital to total risk weighted assets in the same year. The increasing level of non- performing loan rates in banks books, poor loan processing, undue interference in the loan granting process, inadequate or absence of loan collaterals among other things are linked with poor and ineffective credit risk management that negatively impact on banks performance. It is therefore crucial to analyse whether the credit risk indicators are affecting the financial performance of the banks in the study attempting to make a modest contribution to literature on credit risk.

According to Mudge (2000) a consistent framework for evaluating firm wide risk and return across diverse financial activities is a key to evaluating the benefits of potential mergers among banking firms. Brown and Manassee (2004) observe that credit risk arose before financing of business ventures. Banks and other intermediaries can transfer the payment delays and the credit risk among producers, or between producers and outside investors (Demirguc-kunt\&Huzinga, 2000).Afriyieet al. (2012) examined the impact of credit risk on the profitability of rural and community banks in the BrongAhafo Region of Ghana and indicated a significant positive relationship between non-performing loans and rural banks' profitability revealing that, there are higher loan losses but banks still earn profit.Kithinji (2010) analyzed the effect of credit risk (measured by the ratio of loans and advances on total assets and the ratio of non-performing loans to total loans and advances) on return on total asset in Kenyan banks. The study showed that the bulk of the profits of commercial banks is not influenced by the amount of credit and non-performing loans, implying that there are other variables apart from credit and non-performing loans impact on banks' profit. 


\subsection{Commercial Banks in Kenya}

According to CBK (2013) Supervision Report as of December 2013 out of the 44 commercial banks 30 of them are domestically owned and 14 are foreign owned. In terms of asset holding, foreign banks account for about $34 \%$ of the banking assets as of 2013 . The Kenyan financial system is dominated by commercial banks as financial intermediaries that act as conduits between the surplus economic units and the deficit economic units (Beck, Demirguc-Kunt\& Levine, 2009). According to Rose (2002), a commercial bank is simply a business corporation organized for the purpose of maximizing the value of the shareholders' wealth invested in the firm at an acceptable level of risk. Even if the institution is member-owned or has a philanthropic motivation, the principle of earning a profit still applies. Obtaining a positive net income is imperative for permanency and sustainability. What may differ between a for-profit and a not-for-profit institution is the degree of profit accumulation and the use of those profits.

Commercial banks are licensed and regulated pursuant to the provisions of the Banking Act and the Regulations and Prudential Guidelines issued thereunder. They are the dominant players in the Kenyan Banking system and closer attention is paid to them while conducting off-site and on-site surveillance to ensure that they are in compliance with the laws and regulations. The banking industry has been earmarked as a key pillar to the achievement of vision 2030 (a long-term strategy to achieve sustainable growth by year 2030) through increased savings, encouragement of Foreign Direct Investment (FDI), safeguarding the economy from external shocks as well as propelling Kenya to become a leading financial centre in Eastern and Southern Africa.

Government of Kenya statistics reported an alarming 45\% annual average increase in number of economic crimes (GOK, 2011). Banks in Kenya lost a staggering Kshs $1.7 \mathrm{bn}$ in the three months August to October 2010. Commercial banks lost Kshs 761Milion in the first six months of 2010 through fraud, according to the Central Bank of Kenya (PwC, 2011). The Government of Kenya earmarked the banking sector as one of the key pillars to the achievement of vision 2030. Within the Medium Term Plan (2008-2012) under vision 2030, some of the target areas include development of a safe and reliable payments system that will ensure smooth transfer and settlement of funds between customers and banks as well as between banks. Towards this end, the use of mobile phone networks, internet, payment cards, operational resilience and security will be pursued in order to increase trust, integrity and confidence in the ICT based payment systems (Government of Kenya, 2008). In comparison with other East African economies, Kenya's banking sector has for many years been credited for its size and diversification. Private credit to GDP, a standard indicator of financial development, was $23.7 \%$ in 2008, compared to a median of $12.3 \%$ for Sub-Saharan Africa. Based on the same indicator Kenya is ahead of Tanzania which has $12.3 \%$ and Uganda with 7.2\% (Beck, Demirguc-Kunt\& Levine, 2009).

\subsection{Finance distress theory}

\section{Literature Review}

Baldwin and Scott (1983) purported that when a firm's business deteriorates to the point where it cannot meet its financial obligation, the firm is said to have entered the state of financial distress. The first signals of financial distress are violations of debt payments and failure or reduction of dividends payouts. Whitaker (1999) defines entry in financial distress as the first year in which cashflows are less than current maturities' long-term debt. The firm has enough to pay its creditors as long as the cashflows exceeds the current debt obligations. The key factor in identifying firms in financial distress is their inability to meet contractual debt obligations.

However, substantial financial distress effects are incurred well prior to default. Wruck (1990) stated that firms enter into financial distress as a result of economic distress, declines in their performance and poor management especially on risks. Boritz (1991) depicts a process of a financial distress that begins with an incubation period characterized by a set of bad economic conditions and poor management which commits costly mistakes. The relevance of the financial distress theory emanates from the liquidity and credit risk facing a firm. In the case of commercial banks, in ability to provide cash to depositors and loans to borrowers as and when the demand may constitute a liquidity crisis. Other creditors also need to be taken into account when firms are putting in place risk management measures. Credit risks in banks also need to be addressed since it may lead to financial distress. Loan portfolio management is an important determinant of the firm's liquidity. The banks should manage the credit and liquidity risk in order to avoid the financial distress. The foregoing instigated the question as to what is the effect of the credit risks on the financial performance.

\subsection{Credit Riskand Financial Performance}

The main purpose of a bank existence is to accept deposits as well as to grant credit facilities, therefore inevitably exposed to credit risk. Credit risk is the most significant risk faced by banks and the success of their business depends on accurate measurement and efficient management of this risk to a greater extent than any other risks (Gieseche, 2004). According to Chen and Pan (2012), credit risk is the degree of value fluctuations in 
debt instruments and derivatives due to changes in the underlying credit quality of borrowers and counterparties. Coyle (2000) defines credit risk as losses from the refusal or inability of credit customers to pay what is owed in full and on time. Credit risk is the exposure faced by banks when a borrower (customer) defaults in honouring debt obligations on due date or at maturity. This risk interchangeably called counterparty risk is capable of putting the bank in distress if not adequately managed.

Empirical evidences and results of various studies show a mixed trend on the effect of credit risk on bank performance. While some established a negative relationship between credit risk and bank performance, other found a positive relationship. In the extreme is the study that found no relationship between credit risk and bank profitability. Also, some of the studies considered the overall risk as a determinant of bank performance, others focus on credit risk as the major risk affecting bank profitability.

Hosna et al. (2009) studied the relationship between non-performing loan and capital adequacy ratios and profitability for four Swedish banks covering a period of 2000 to 2008 . The study showed that rate of nonperforming loan and capital adequacy ratios was inversely related to ROE though the degrees vary from one bank to the other. Such inverse relationships between profitability, performance and credit risk measures were also found in other studies (Achou and Tenguh, 2008; Kolapoet al., 2012; Musyoki and Kadubo (2011).

Kithinji (2010) analyzed the effect of credit risk measured by the ratio of loans and advances on total assets and the ratio of non-performing loans to total loans and advances on return on total asset in Kenyan banks from 2004 to 2008 . The study found that the bulk of the profits of commercial banks are not influenced by the amount of credit and non-performing loans. The study provides the rationale to consider other variables that could impact on bank's performance and also a longer period of the study so as to capture the real picture of the banks' performance. Hence this study included the impact of liquidity and market risk as components of the financial risk.

Afriyieet al. (2011) examined the impact of credit risk on the profitability of rural and community banks in the BrongAhafo Region of Ghana. The study used the financial statements of ten rural banks from the period of 2006 to 2010 (five years) for analysis. The panel regression model was employed for the estimation. In the model, of Return on Equity (ROE) and Return on Asset (ROA) were used as profitability indicator while Non-Performing Loans Ratio (NLPR) and Capital Adequacy Ratio (CAR) as credit risk management indicators. The findings indicated a significant positive relationship between non-performing loans and rural banks' profitability revealing that, there are higher loan losses but banks still earn profit. He found that there is a relationship between the credit risk management and profitability of selected rural banks in Ghana.

Kargi (2011) evaluated the impact of credit risk on the profitability of Nigerian banks. Financial ratios as measures of bank performance and credit risk were collected from the annual reports and accounts of sampled banks from 2004-2008 and analyzed using descriptive, correlation and regression techniques. The findings revealed that credit risk management has a significant impact on the profitability of Nigerian banks. It concluded that banks' profitability is inversely influenced by the levels of loans and advances, non-performing loans and deposits thereby exposing them to great risk of illiquidity and distress. The comprehensive analysis of credit risks including capital to risk weighted asset ratio needed to be considered. Hence the current study considered these pertinent variables in its analysis.

Kolapoet al. (2012) using panel model approach carried out an empirical investigation into the quantitative effect of credit risk on the performance of commercial banks in Nigeria over the period of 11 years (2000-2010) from the selected five commercial banks. The traditional profit theory was employed to formulate profit, measured by Return on Asset (ROA), as a function of the ratio of Non-performing loan to loan and advances (NPL/LA), ratio of Total loan and Advances to Total deposit (LA/TD) and the ratio of loan loss provision to classified loans (LLP/CL) as measures of credit risk. Panel model analysis was used to estimate the determinants of the profit function. The results showed that the effect of credit risk on bank performance measured by the Return on Assets of banks is cross-sectional invariant. Their findings show that profitability is reduced by increase of non-performing loan and loan loss provision and that the effect of credit risk is similar across banks all banks considered in the study. However, an increase in total loan and advances increase the profitability.

Poudel (2012) explored various parameters pertinent to credit risk management as it affect banks' financial performance in Napel using parameters such as default rate, cost per loan assets and capital adequacy ratio. Correlation and regression models were used to analyze the data where the study revealed that all these parameters have an inverse impact on banks' financial performance. Observation of t-test indicated that there is significant negative relationship between return on assets and independent variable which are default rate and capital adequacy ratio.

Afriyieet al. (2012) examined the impact of credit risk indicators on the profitability of rural and community banks in the BrongAhafo Region of Ghana. The study used the financial statements of ten rural banks from the period of 2006 to 2010 for analysis. The panel regression model was employed for the estimation where the definition of Return on Equity (ROE) and Return on Asset (ROA) were used as 
profitability indicator while Non-Performing Loans Ratio (NLPR) and Capital Adequacy Ratio (CAR) as credit risk management indicators. The findings indicate a significant positive relationship between non-performing loans and rural banks' profitability revealing that, there are higher loan losses but banks still earn profit. This indicates that, rural banks do not have sound and effective credit risk management practices. Their study failed to consider other risk factors that affect that affect the bank's profitability.

Onaolapo (2012) analyzed the relationship between the credit risk management efficiency and financial health in selected Nigerian commercial banking sector. Data collections are mainly secondary spanning a 6 years period before and after consolidation programme (2004 to 2009). The study hypothesized negative relationship between Efficiency of Credit Risk Management, bank performance and operational effectiveness. The study used regression analysis and unit root test was used verify order of integration for each time series data employed. Findings indicate minimal causation between Deposit Exposure (DE) and performance but greater dependency on operational efficiency parameters. In the study, test of stationary properties was conducted using Augmented Dickey Fuller (ADF) which indicated that all variables were non-stationary while the pair wise Granger causality suggested that Deposit Exposure performance influence does not hold for the Nigerian Commercial banking sector. The study captured most of variables or measures of credit risk management except the asset quality. Other advanced methods such as generalized method of moments least needed to have been used to analyse the data.

Ogboi and Unuafe (2013) examined the impact of credit risk and capital adequacy on banks financial performance in Nigeria. Their study used a time series and cross sectional data from 2004-2009 obtained from selected banks annual reports and accounts in Nigeria. Secondary data for the study were obtained from the published financial statement of six out of twenty one banks operating as at December 2009 which were selected by purposive sampling technique. Panel data model was used to estimate the relationship that exists among loan loss provisions (LLP), loans and advances (LA), non-performing loans (NPL) and capital adequacy (CA) which were the independent variables and return on asset (ROA) as the dependent variable to measure the profitability of the banks. The findings showed that sound credit risk management and capital adequacy impacted positively on bank's financial performance with the exception of loans and advances which was found to have a negative impact on banks' profitability during that period.

Marshal and Onyekachi (2014) carried out an empirical investigation on the effect of credit risk and performance of banks in Nigeria over the period of 15 year (1997-2011) on five banking firms that .Data were sourced from the annual reports and accounts statements/sheets of the banks in the sample which was timeseries and cross sectional data and estimated using panel data regression techniques. The result shows that there is a positive relationship between Ratio of non- performing loans to loan and advances (LogNPL) and banks performance (LogROA). Their study indicated that banks in the study carry a very minimal level of nonperforming loans in their loan portfolio and as such this does not conform to our apriori expectations. Their findings were also that there exist a positive relationship between ratio of loan and advances to total deposit $(\operatorname{LogLA})$ and banks performance (LogROA). The conclusion was that increase in loan and advances increases banks performance through interest income generated from loan and advance.

\subsection{Model Specification}

\section{Results and Discussion}

Return on equity was considered as a measure for financial performance and therefore, was used as the dependent variable whereas capital to risk weighted assets, asset quality, loss loan provision and loan and advances were considered as independent variables. The study assumed that the independent variables and the dependent variable had a general multiplicative Cobb Douglas functional relationship shown in model 1.

$$
R O E=f(C R W A R, L L P R, A Q R, L A R)
$$

Upon linearization and parametization the long run model was specified as:

$$
R O E_{i t}=\beta_{0}+\beta_{1} C R W A R_{i, t}+\beta_{2} L L P R_{i, t}+\beta_{3} A Q R_{i, t}+\beta_{4} L A R_{i, t}+\alpha_{i}+\varepsilon_{i, t}
$$

And the short run model as:

$$
\begin{aligned}
& R O E_{i, t}=\beta_{0}+\lambda R O E_{i, t-1}+\beta_{1} C R W A R_{i, t}+\beta_{2} L L P R_{i, t}+\beta_{3} A Q R_{i, t}+\beta_{4} L A R_{i, t}+\alpha_{i}+\varepsilon_{i, t} \\
& \text { Where } i=1, \ldots \ldots .43 \quad t=1,2 \ldots \ldots 10
\end{aligned}
$$

In which $\mathrm{ROE}_{\mathrm{i}, \mathrm{t}}$ represents the performance of Bank $i$ at time $t, \beta_{0}$ stands for the model constant or intercept, $\beta_{\mathrm{i}}$ stands for the coefficients of the independent variables. $R O E_{i, t-1}$ is lagged bank performance, $\mathrm{CRWAR}_{\mathrm{i}, \mathrm{t}}$ stands for capital to risk weighted assets ratio of bank $\mathrm{i}$ at time $t, \mathrm{LLPR}_{\mathrm{i}, \mathrm{t}}$ is the Loss Loan Provision ratio of bank $i$ at time $t, \mathrm{AQR}_{\mathrm{i}, \mathrm{t}}$ is the Asset Quality ratio of bank $i$ at time $t, t$ and $\mathrm{LAR}_{\mathrm{i}, \mathrm{t}}$ is the Loan and Advances ratio of bank $i$ at time t. $\alpha_{i}$ is the bank specific effect that is assumed to be normally distributed with a constant variance and $\varepsilon_{i t}$ is the idiosyncratic error term which is assumed to have a normal distribution. 


\subsection{Summary Statistics of Data}

Table 3.1: Summary Statistics for the Data Set

\begin{tabular}{|l|l|l|l|l|l|}
\hline Variables & $\mathrm{N}$ & Mean & Standard Deviation & Min & Max \\
\hline ROE & 416 & 0.178 & 0.170 & -0.909 & 0.500 \\
\hline CRWAR & 415 & 0.242 & 0.143 & 0.057 & 1.102 \\
\hline AQR & 396 & 0.166 & 0.305 & 0.002 & 4.110 \\
\hline LLPR & 406 & 0.061 & 0.154 & 0.001 & 2.669 \\
\hline LAR & 411 & 0.747 & 0.278 & 0.205 & 3.102 \\
\hline
\end{tabular}

Table 3.1 shows that the number of observations per each variable varied. This may be explained by the unbalanced nature of the panel data used in the analysis. Table 3.1 additionally shows that on average the overall mean return on equity, core capital to risk weighted asset ratio, asset quality and loan loss provision were 17.8, 24.2, 16.6 and 6.08 per cent respectively. Therefore, over the period the banks were positively profitable, adequately capitalized and experienced some relatively high levels of deterioration in asset quality during the study period.

Table 3.2: Pair correlation between credit risk components and Return on Equity

\begin{tabular}{|l|l|l|l|l|l|}
\hline & ROE & CRWAR & AQR & LLPR & LAR \\
\hline ROE & 1 & & & & \\
\hline CRWAR & -0.251 & 1 & & & \\
\hline & $(0.000)$ & & & & \\
\hline AQR & -0.521 & 0.163 & 1 & & \\
\hline & $(0.000)$ & $(0.001)$ & & & \\
\hline LLPR & -0.389 & 0.246 & 0.846 & 1 & \\
\hline LAR & $(0.000)$ & $(0.000)$ & $(0.000)$ & & \\
\hline & -0.073 & -0.181 & -0.034 & -0.031 & 1 \\
\hline
\end{tabular}

Key: P-values in parenthesis

Table 3.2 shows that return on equity is significantly negatively correlated with all the components of credit risk except for loans and advances. This is at variance with the findings of Kolapoet al. (2012) who found positive relationship between profitability and loan and advances. Therefore, in the regression analysis it was expected that the coefficients of core capital to risk weighted assets, asset quality and loan loss provision will be negative. However, from correlation analysis the study could not tell whether or not the coefficient of loans and advances will be significant and the nature of signage of its coefficient.Additionally table 3.2 shows that the correlation between asset quality and loan loss provision ratio is positive and near perfect. To avoid endogeneity problems loan loss provision was dropped from the regression analysis.

\subsection{Skewness, Kurtosis and Normality Test of One Way Error Component for panel Models}

The extension of the Bera-Jarque normality test by Galvao, Montes-Rojas, Sosa-Escudero and Wang (2013) made the normality test a standard test that can be performed prior to the estimation of the model or even after the estimation of the model. The normality test of each of the components in the error term is shown in table 3.3 for each model.

Table 3.3 :Skewness Kurtosis and Normality of One way Error component for Panel Models

\begin{tabular}{|l|l|l|l|l|l|l|l|}
\hline \multicolumn{3}{|c|}{ Skewness } & \multicolumn{2}{l|}{ Kurtosis } & Normality \\
\hline Model & Error Component & Z Statistic & P-Value & Z Statistic & P-Value & Chi Statistic & P-Value \\
\hline \multirow{3}{*}{3.1} & $\mathrm{e}$ & -1.48 & 0.139 & 2.31 & 0.0871 & 7.53 & 0.0631 \\
\cline { 2 - 8 } & $\mathrm{u}$ & -3.37 & 0.1243 & 2.91 & 0.1561 & 2.24 & 0.0732 \\
\hline
\end{tabular}

Table 3.3 shows the distribution of the one way error component in the linear panel model. The individual specific heterogeneity component is $\mathrm{u}$ while the rest of the error term is e. $\mathrm{u}$ varies with banks only while e varies across banks and time. To use the variance of the combined error term error term to test the significance of the coefficients in the estimates of the model requires that each component is normally distributed. Therefore, the skewness and kurtosis of the components should be symmetrical to that of the normal distribution.

Table 3.3 shows that the $\mathrm{z}$ statistic for the skewnessof all the components in model 1 have $\mathrm{z}$ statistics with corresponding $\mathrm{p}$-values that are greater than 0.01 . Thus the $\mathrm{Z}$ statistics are less than the tabulated at five per cent level of significance. Therefore, the null hypothesis of symmetrical skewness with normal distribution is not rejected for any component in all the models. Thus the components are neither negatively nor positively skewed compared to the normal distribution. 
Table 3.3 further shows that the $\mathrm{z}$ statistics for kurtosis of all the components of the error terms in all the models have $\mathrm{p}$-values greater than 0.1 . Therefore the $\mathrm{z}$ statistics are less than the tabulated statistics at five per cent level of significance. Thus the null hypothesis that each components kurtosis is symmetric to that of the normal distribution is not rejected at five per cent level of significance. Therefore the components of the error term are neither more nor less peaked than the normal distribution.

The overall normality test of each component of the error term in model 1 has chi statistics with corresponding p-value that are greater than 0.1 . Therefore, the chi statistics are less than the critical values at five per cent level of significance. Thus the null hypothesis that each component is normally distributed is not rejected at five per cent level of significance for all the models. Therefore the error components are normally distributed for model 1 .

\subsection{Empirical findings}

The study presents the findings as follows; (1) each long run model is presented separately and its post-estimation diagnostics discussed to establish the reliability of the findings (2) the study discriminates between the long run models using Hausman test (3) the study presents the naïve OLS and fixed effects estimates of the short run specification to establish the range where the coefficient of lagged return on equity should lie in the Generalized Method of Moments (GMM) specification (4) the study estimates and presents the GMM specification while presenting the instruments used and discussing the post-estimation diagnostics of the GMM model. Finally (5) the study presents a comparative summary of all the models and tests the hypotheses both in the short and in the long run.

The first long run specification of model 1 was the fixed effects model whose findings are shown in table 3.4.

Table 3.4: Fixed Effects Estimates for Model 1

\begin{tabular}{|c|c|c|}
\hline \multicolumn{2}{|l|}{ Dependent variable } & ROE \\
\hline \multicolumn{2}{|l|}{ Explanatory Variable } & Coefficient \\
\hline \multicolumn{2}{|l|}{ CRWAR } & $-0.352 * * *$ \\
\hline \multicolumn{2}{|l|}{ AQR } & $-0.194 * * *$ \\
\hline \multicolumn{2}{|l|}{ LAR } & -0.028 \\
\hline \multicolumn{2}{|l|}{ Constant } & $-2.826 * * *$ \\
\hline \multicolumn{3}{|c|}{ Post Estimation Diagnostics } \\
\hline \multirow[t]{4}{*}{ R square } & Within & 0.087 \\
\hline & Between & 0.4181 \\
\hline & Overall & 0.2897 \\
\hline & Rho & 0.589 \\
\hline \multicolumn{2}{|l|}{ F test $(3,320)$} & $10.18 * * *$ \\
\hline chow test & $\mathrm{F}(41,320)$ & $9.47 * * *$ \\
\hline \multicolumn{3}{|l|}{ KEY } \\
\hline p-value $<0.01$ & & **** \\
\hline P-value $<0.05$ & & $* *$ \\
\hline $\mathrm{P}-$ value $<0.1$ & & $*$ \\
\hline
\end{tabular}

Table 3.4 shows that the F statistic is 10.18 and is greater than the critical value at one per cent level of significance. Therefore, the variables which are the credit risk components are jointly significant in explaining the variations in return on equity. The interclass correlation (rho) is 58.9 per cent implying that 58.9 per cent of the variations in return in equity are due to differences across the banks. The within and between R-square is 8.7 per cent and 41.8 per cent respectively. Thus, 8.7 per cent of variations in the return on equity are due to differences within individual banks and 41.8 per cent of the variations are due to differences between the banks. The overall $\mathrm{R}^{2}$ is 28.9 percent, indicating that the variables considered in the model account for about 29 percent change in the dependent variables, while about 71 percent change may be as a result of other variables not addressed by this model.

The chow test statistic is 9.47 and is greater than the critical value at one per cent level of significance. Therefore, the null hypothesis that the fixed effects are equal to zero is rejected at one per cent level of significance. Thus the option of specifying the model as a pooled OLS model over the Fixed effects specification is rejected at one per cent level of significance. The second alternative specification of model 1 is the random effects model whose findings are shown in table 3.5. 
Table 3.5: Model 1 Random Effects Estimates

\begin{tabular}{|c|c|c|}
\hline \multicolumn{2}{|l|}{ Dependent variable } & ROE \\
\hline \multicolumn{2}{|l|}{ Explanatory Variable } & Coefficient \\
\hline \multicolumn{2}{|l|}{ CRWAR } & $-0.381 * * *$ \\
\hline \multicolumn{2}{|l|}{$\mathrm{AQR}$} & $-0.242 * * *$ \\
\hline \multicolumn{2}{|l|}{ LAR } & -0.043 \\
\hline \multicolumn{2}{|c|}{ Constant } & $-3.051 * * *$ \\
\hline \multicolumn{3}{|c|}{ Post Estimation Diagnostics } \\
\hline \multirow[t]{4}{*}{ R square } & Within & 0.086 \\
\hline & Between & 0.434 \\
\hline & Overall & 0.301 \\
\hline & Rho & 0.515 \\
\hline \multicolumn{2}{|l|}{ Wald test $(3,365)$} & $55.69 * * *$ \\
\hline Lm test & Chibar2 & $252.02 * * *$ \\
\hline \multicolumn{3}{|l|}{ KEY } \\
\hline p-value $<0.01$ & & $* * *$ \\
\hline $\mathrm{P}$-value $<0.05$ & & $* *$ \\
\hline $\mathrm{P}-$ value $<0.1$ & & $*$ \\
\hline
\end{tabular}

Table 3.5 shows that the Wald statistic is 55.69 and is greater than the critical value at one per cent level of significance. Therefore, the variables (credit risk components) are jointly significant in explaining the variations in return on equity in the random effects specification.

The interclass correlation (rho) is 55.7 per cent implying that 55.7 per cent of the variations in return in equity are due to differences across the banks as per the random effects model. The coefficient of determinations, R-square shows the within and between values of 8.6 per cent and 43.4 per cent respectively. Thus, 8.6 per cent of variations in the return on equity are due to differences within individual banks and 43.4 per cent of the variations are due to differences between the banks.

The LM test statistic is 252.02 and is greater than the critical value at one per cent level of significance. Therefore, the null hypothesis that the cross sections are not heterogeneous is rejected at one per cent level of significance. Thus the random effects specification is preferred over pooled OLS.

A comparison of the post estimation diagnostics between the Fixed and random effects specification reveals that the conclusions are comparable. For instance when POLS specification is compared with the estimated models it's rejected in both instances. In addition the overall explanatory powers of the specifications are not significantly different; the fixed effect specification explains an overall explanation 29 per cent while the random effects model has an overall explanation of 30 per cent. However, the consistency in post estimation diagnostics does not eliminate the need to discriminate between the models. The Hausman test statistics to discriminate between the specifications are shown in table 3.6.

Table 3.6: Model 1 Hausman Test
\begin{tabular}{|l|l|}
\hline Test statistic Chi(3) & P-value \\
\hline $\mathbf{1 2 . 9 9}$ & $\mathbf{0 . 0 0 5}$ \\
\hline
\end{tabular}

Table 3.6 shows that the test statistics have a chi statistic of 12.99 with three degrees of freedom and a corresponding $\mathrm{p}$ value of 0.005 . Therefore, the null hypothesis that the regressors and individual heterogeneity are strictly exogenous is rejected at one per cent level of significance. Thus the FE specification is preferred over RE specification. Therefore, for the long run specification the fixed effects model should be interpreted.

To establish the bound where the coefficient of lagged profits would lie the naïve OLS was estimated. The OLS estimates over state the coefficient of lagged profits by attributing to it some explanatory power of the error term. Thus the OLS estimate provides the upper bound of the coeffient. The OLS estimates are shown in table 3.7 .

Table 3.7: OLS Estimates for credit risk components

\begin{tabular}{|l|l|}
\hline Dependent variable & ROE \\
\hline Explanatory Variable & Coefficient \\
\hline$R O E_{t-1}$ & $0.604 * * *$ \\
\hline CRWAR & $-0.199 * * *$ \\
\hline AQR & $-0.137 * * *$ \\
\hline LAR & $-0.091 * *$ \\
\hline Constant & $-1.344 * * *$ \\
\hline Post Estimation Diagnostics & 0.628 \\
\hline R square & $132.31 * * *$ \\
\hline F statistic $(4,314)$ & $* * *$ \\
\hline KEY & $* *$ \\
\hline p-value $<0.01$ & $*$ \\
\hline P-value $<0.05$ & \multicolumn{2}{|l|}{} \\
\hline $\mathrm{P}-$ value $<0.1$ & \\
\hline
\end{tabular}


Table 3.7 shows that the coefficient of lagged return on equity is 0.604 . Therefore, the upper bound for the coefficient of lagged return on equity in the GMM specification of the short run model should be 0.604. To get the lower bound the fixed effect estimates of the short run specification are used. Fixed effect estimation understates the coefficient by denying the lagged dependent variable some of its explanatory power, thus providing the lower bound. The fixed effect estimates of the short run specification are shown in table 3.8.

Table 3.8: Fixed Effects Estimates for credit risk components

\begin{tabular}{|l|l|}
\hline Dependent variable & ROE \\
\hline Explanatory Variable & Coefficient \\
\hline$R O E_{t-1}$ & $0.247 * * *$ \\
\hline CRWAR & $-0.257 * *$ \\
\hline AQR & $-0.148^{* * *}$ \\
\hline LAR & -0.039 \\
\hline Constant & $-2.075^{* * *}$ \\
\hline Post Estimation Diagnostics \\
\hline R square & 0.164 \\
\hline F statistic $(4,314)$ & $13.34 * * *$ \\
\hline KEY & $* * *$ \\
\hline p-value $<0.01$ & $* *$ \\
\hline P-value $<0.05$ & $*$ \\
\hline P-value $<0.1$ & \\
\hline
\end{tabular}

Table 3.8 shows the fixed effects estimates of the short run specification of model 1 . The coefficient of lagged return on equity is 0.247 . Thus the lower bound of lagged return on equity in the GMM specification should be 0.247 . Specifically if the estimate is $\lambda$, it should lie in the interval $0.247 \leq \lambda \leq 0.604$.

Roodman (2006) states that when the data feature a large numbers of countries (N) relative to the time period (T), the GMM-difference estimator proposed by Arellano and Bond (1991) and the GMM-system estimator by Arellano and Bover (1995) and Blundell and Bond (1998) work well. These two estimators are typically used to analyse micro panel datasets (Eberhardt, 2012). To obtain consistent estimates of the short run spefication one step system GMM is used. The estimates are shown in table 3.9.

Table 3.9: One Step System GMM Estimates

\begin{tabular}{|l|l|}
\hline Dependent variable & ROE \\
\hline Explanatory Variable & Coefficient \\
\hline$R O E_{t-1}$ & $0.579 * * *$ \\
\hline CRWAR & -0.146 \\
\hline AQR & $-0.086^{*}$ \\
\hline LAR & $-0.168^{* * *}$ \\
\hline Constant & $-1.187^{* * *}$ \\
\hline Post Estimation Diagnostics & \\
\hline Hansen J test & 40.5 \\
\hline AR $(1)$ & $-3.62^{* * *}$ \\
\hline AR $(2)$ & -0.92 \\
\hline KEY & $* * *$ \\
\hline p-value $<0.01$ & $* *$ \\
\hline P-value $<0.05$ & $*$ \\
\hline $\mathrm{P}-$ value $<0.1$ &
\end{tabular}

Table 3.9 shows the one step system GMM estimates for the short run specification of model 1 . The table shows that the coefficient of the lagged return on equity is 0.579 . The coefficient, therefore, lies in the acceptable range of $0.247 \leq \lambda \leq 0.604$ etablished by the naïve OLS estimates and fixed effects estimates of the short run model 1 . This points to consistency of estimates.

Table 3.9 further shows that the Hansen $\mathrm{J}$ statistic is 40.5 with a corresponding p-value greater than 0.1 . Therefore, the null hypothesis of the validity of the overidentifying restrictions for the instruments is not rejected at one per cent level of significance. Therefore, the instruments employed by the model are appropriate and lead to precise consistent estimates.

In addition table 3.9 shows that the test of autocorrelation in the error terms. The $\mathrm{AR}(1)$, first order autocorrelation, test statistic is -3.62 and is greater than the critical value at one per cent level of significance. Therefore the null hypothesis that disturbance term (error terrm) has no first order serial correlation is rejected at one per cent level of significance. This is expected because of the dynamic specification of model 1 and therefore, points to correct specification. The test statistic for second order serial correlation in the error term is 0.92 with a coreresponding p-value that is greater than 0.1 . Therefore, at one per cent level of significance the 
null hypothesis that there is no second order serial correlation in the disturbance term is not rejected at one per cent level of significance. This permits the use of insturments from the second lag and differences further supporting the argument of correct short run specification of model 1 using the one step GMM estimates.

To Summarize the findings necessary to test the first hypothesis in the short run and in the long run. The findings in table 3.4 through 3.9 are summarized in table 3.10 .

Table 3.10: Effects of Credit Risk on Financial Performance of Commercial Banks in Kenya

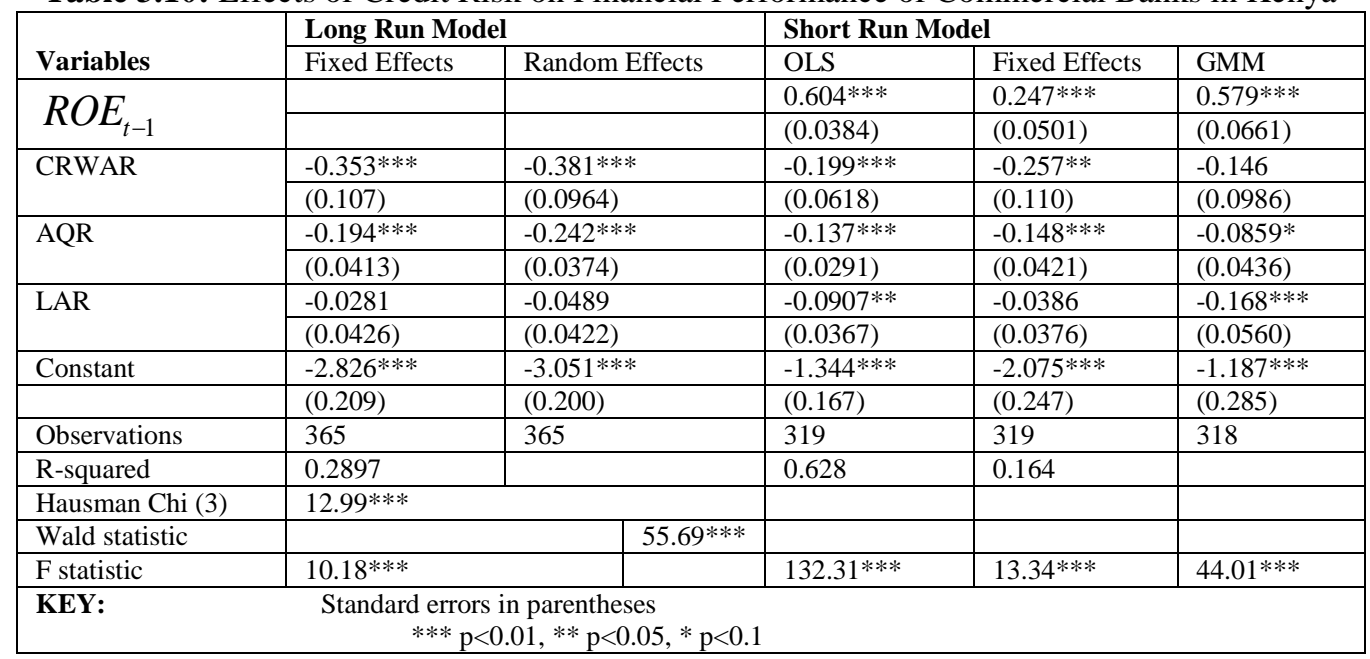

Table 3.10 shows that the signage of the coefficients is comparable be it in the short run or in the long run. The magnitude of the coefficients is comparable for the long run model but significantly differs in the short run specification as expected. Based on the post estimation diagnostics and theory, only the fixed effects model and the GMM specification results should be interpreted in the long run and short run respectively.

Table 3.10 shows that in the long run the coefficient of capital to risk weighted assets is -0.353 with a p-value less than 0.01. Thus, the coefficient is significantly different from zero at one per cent level of significance. Therefore, the null hypothesis that core capital to risk weighted assets has a significant negative effect on financial performance of commercial banks in Kenya is not rejected at one per cent level of significance. The magnitude of the coefficient is 0.353. Since the dependent variable, ROE, as well as core capital to risk weighted assets ratio enter equation 1 in $\log$ form, a one per cent increase in the risk weighted assets ratio reduces return on equity by 35.3 percentage points in the long run holding other factors constant.

Since capital to risk weighted assets ratio explains strength of the bank, it improves the solvency of the bank and capacity to absorb the loan loss when CRWAR is high. The ratio is expected to increase when the banks increase the capital and reduce when the banks increase the risk weighted assets. According to the study the former will reduce the return on equity as a result of holding excess capital. The latter will reduce the ratio as risk weighted assets comprise of the high loans that may result to increase in profitability of the commercial banks.

In the short run the coefficient of core capital to risk weighted assets is -0.146 with a p-value greater than 0.1. Therefore, the coefficient is not significant at either 10, five or one per cent. Thus in the short run the null hypothesis that core capital to risk weighted assets has a significant negative effect on financial performance of commercial banks in Kenya is rejected at one per cent level of significance. Thus in the short run growth in core capital to risk weighted assets does not influence financial performance of commercial banks.

Table 4.19 further shows that in the long run the coefficient of asset quality is -0.194 with a $p$ value less than 0.01. Thus, the coefficient is significantly different from zero at one per cent level of significance. Therefore, the null hypothesis that asset quality has a significant negative effect on financial performance of commercial banks in Kenya is not rejected at one per cent level of significance. The magnitude of the coefficient is 0.194 . Since the dependent variable, ROE, as well as asset quality enter equation 1 in log form, one per cent deterioration in asset quality reduces return on equity by 19.4 percentage points in the long run holding other factors constant.

In the short run the coefficient of asset quality is -0.0859 with a p-value less than 0.1 . Therefore, the coefficient is significant at 10 per cent. Thus in the short run the null hypothesis that asset quality has a significant negative effect on financial performance of commercial banks in Kenya is not rejected at 10 per cent level of significance. The magnitude of the coefficient is 0.0859 . Thus in the short run deterioration in asset quality by one per cent causes a decline in return in equity of 8.6 percentage points holding other factors constant. These results indicate a significant negative relationship between non-performing loans to total loans 
and commercial banks' profitability revealing that, there are higher loan losses which causes declines in banks' profit.

These results are expected as banks take deposits and use the same to advance loans and the costs associated with these loans such as insurance costs reduces the profitability margins of the bank. Increase in the portfolio at risk may be caused by increase in loan books and hence an upward increase in insurance costs. Return on equity (ROE) is the reward to the shareholders for the funds they have invested with the banks after other financiers and costs, including liabilities such as taxes have been paid. Therefore increased portfolio at risk will reduce the revenue aspect and increase the cost associated as indicated by the analysis of non-performing loans. The correlation between non-performing loans and return on equity cannot be ignored.

An increase in the doubtful assets, which does not accumulate income, obliges financial entities to assign a significant portion of its gross margin to provisions in order to cover expected credit losses, consequently profitability is expected to affected. The results also concur with findings of Kargi (2011) that banks' profitability is inversely influenced by the levels of non-performing loans and deposits thereby exposing them to great risk of illiquidity and distress. The results are also consistent with Kolapoet al. (2012), Ruziqa (2013), Claudine and Felix (2008) findings that return on equity (ROE) measuring profitability was inversely related to the ratio of non-performing loan to total loan of financial institutions thereby leading to a decline in profitability. This indicates that, Kenyan commercial banks are required to improve on sound and effective management practices on default.

With respect to loan and advances table 4.19 shows that in the long run the coefficient of loans and advances is -0.0281 with a p-value greater than 0.1 . Therefore, the coefficient is neither significant at 10 , five nor one per cent. Thus in the long run, the null hypothesis that loans and advances have a significant negative effect on financial performance of commercial banks in Kenya is rejected at one per cent level of significance. Therefore, other things being equal in the long run changes in loans and advances do not influence financial performance of commercial banks in Kenya.

In the short run the coefficient of loans and advances is -0.168 with a p-value less than 0.01 . Therefore, the coefficient is significant at either one per cent. Thus in the short run the null hypothesis that loans and advances have a significant negative effect on financial performance of commercial banks in Kenya is not rejected at one per cent level of significance. The magnitude of the coefficient is 0.168 . Thus in the short run a one per cent increase in loans and advances causes a decline in return on equity of 16.8 percentage points holding other factors constant.

The above results are expected because loans and advances are risky assets and their large share in bank's assets means a growth of the bank's exposure to risks. Thus, a high value of this indicator could also mean a possible weakening of the bank's assets quality with a negative effect upon profitability which is proxied by ROE. The effect of loan loss reserve to gross loan on profitability is negative as earlier literature by Kolapo et al. (2012) and Sufian (2009) which indicated that profitability will be reduced as banks use more profit as buffer against their loan loss. Inorder to reduce loan loss so as to reduce reserve ratio and increase the profitability, prudential credit management is required.

To jointly test whether the components of credit risk negatively influence the financial performance of commercial banks in Kenya $\mathrm{F}$ test was used. The test has a null hypothesis that all the coefficients of the components of credit risk are jointly equal to zero. Table 3.10 shows that in the long run the F statistic is 10.18 and is greater than the critical value at one per cent level of significance. Therefore, in the long run null hypothesis one that credit risk has a significant negative effect on the financial performance of commercial banks in Kenya is not rejected at one per cent level of significance.

In the short run the F statistic is 44.01 and is greater than the critical value at one per cent level of significance. Thus in the short run null hypothesis one that credit risk has a significant negative effect on the financial performance of commercial banks in Kenya is not rejected at one per cent level of significance. Thus credit risk influences financial performance of commercial banks in Kenya both in the short run and in the long run.

The results of this study are in line with the study's prior expectation, credit risk is negatively and significantly related to bank performance. This implies that bank increased exposure to credit risk reduces profits. This may result by the fact that health of a bank's loan portfolio may be reflected by changes in credit risk and affect the performance of the institution as indicated by Cooper et al. (2003).

The findings of this study concur with studies by (Afriyieet al. 2011; Hosnaet al., 2009; Ogboi and Unuafe, 2013; Marshal and Onyekachi, 2014) explained that there exist a significant negative association between credit risk components and financial performance. The study by Kithinji (2010) gives evidence that profits of commercial banks are not influenced by the amount of credits or loans. The results may be explained since an asset or loan become irrecoverable, in case of outright default or the risk of delay in servicing of loans and advances. Thus, when this occurs or becomes persistent, the performance, profitability, or net interest income of banks is affected.Duca and McLaughlin (1990) conclude that variations in bank profitability are 
largely attributable to variations in credit risk, since increased exposure to credit risk is normally associated with decreased firm profitability. These triggers a discussion concerning commercial banks that are exposed to highrisk loans tend to have higher the accumulation of unpaid loans and the lower the profitability. From the study a conclusion can be made that not the volume of loans but the quality of loans made.

\section{Summary, Conclusion and Recommendations}

The objective sought to determine the effect of credit risk on profitability of commercial banks. All other factors held constant only $28.97 \%$ of the variation in profitability can be explained by change in credit risk. The findings revealed that bank credit risk has a significant negative effect on the financial performance of commercial banks in Kenya both in the short run and in the long run. This implies that bank increased exposure to credit risk reduces profits. This may result by the fact that health of a bank's loan portfolio may be reflected by changes in credit risk and affect the financial performance of the commercial banks. This indicates that poor asset quality or high non-performing loans to total asset related to poor bank performance. Thus, it is possible to conclude that banks with high asset quality and low non-performing loan are more profitable than the others. The capital may also be reduced by increase of loan loss provision which affects the profitability.

From above findings, it is recommended that management of Kenyan commercial banks should enhance their capacity in credit analysis, appraisals and loan administration. Clear credit policies and lending guidelines should be established. Management also is required to make sure that the terms and conditions are adhered to in loans approval.The study noted that credit risk though significantly affect the financial performance may not be the major factor that affect determinants of Kenyan banks profitability. Further research needs to be carried on other bank risks and factors.

\section{References}

[1]. Basel Committee on Bank Supervision, BCBS (2001). Overview of the new baselcapital accord. Technical report, Basel Committee on Bank Supervision, CH-4002Basel, Switzerland. Consultative Document.

[2]. Coyle, B. (2000). Framework for Credit Risk Management, London: Chartered Institute of Bankers,

[3]. Kargi, H. S. (2011). Credit Risk and the Performance of Nigerian Banks. Ahmadu Bello University, Zaria.

[4]. Mudge, D. (2000). The Urge to Merge. Risk Magazine, 64.

[5]. Brown F and Manassee P (2002), "The Information Content of the Term Structure of Interest Rates: Theory and Evidence"; Monetary and Fiscal Policy Division

[6]. Demirguc-Kunt, A. and Huzinga, H. (1999). Determinants of Commercial Bank Interest Margins and Profitability: Some International Evidence, The World Bank Economic Review, 13(2), 379-40

[7]. Afriyie, H. O., \&Akotey, J. O. (2012). Credit risk management and profitability of selected rural banks in Ghana. Ghana: Catholic University College of Ghana.

[8]. [8] Kithinji, A. M. (2010). Credit risk management and profitability of commercial banks in Kenya. School of Business, University of Nairobi, Nairobi.

[9]. Rose, P.S. (2002). Commercial Bank Management.. (5th ed.), USA:.McGraw-Hill/Irwin

[10]. Baldwin, C. Y., \& Mason, S. P. (1983). The resolution of claims in financial distress the case of Massey Ferguson. The Journal of Finance, 38(2), 505-516.

[11]. Beck, T., Demirgüç-Kunt, A., \& Levine, R. (2009). Financial institutions and markets across countries and over time-data and analysis. World Bank Policy Research Working Paper Series, Vol.

[12]. Whitaker, R. B. (1999). The early stages of financial distress. Journal of Economics and Finance, 23(2), 123-132.

[13]. Wruck, K. H. (1990). Financial distress, reorganization, and organizational efficiency. Journal of financial economics, 27(2), 419444.

[14]. Boritz,J.E. (1991). The Going concern assumptions. Accounting and Auditing complications: Toronto: Canadian Institute of Chartered Accountants.

[15]. Giesecke, K. (2004). Credit risk modeling and valuation: An introduction.Available at SSRN 479323.

[16]. Chen, K. and Pan, C. (2012). An Empirical Study of Credit Risk Efficiency of Banking Industry in Taiwan, Web Journal of Chinese Management Review, 15(1), 1-16. 9.

[17]. Hosna, A., Manzura, B., \&Juanjuan, S. (2009). Credit risk management and profitability in commercial banks in Sweden. rapport nr.: Master Degree Project 2009: 36

[18]. Achou, T. F., \&Tenguh, N. C. (2008). Bank performance and credit risk management. Master Degree Project, Finance Universitu of Skodve School of Technology and Society.

[19]. Kolapo, T. F., Ayeni, R. K., \&Oke, M. O. (2012). Credit risk and commercial banks' performance in Nigeria: a panel model approach. Australian Journal of Business and Management Research,2(2), 31.

[20]. Musyoki D, \&Kadubo A. S (2011). The impact of credit risk management on the financial Performance of Banks in Kenya for the Period 2000-2006. International Journal of Business and Public Management 2(2), 72-80.

[21]. Poudel, R. P. S. (2012). The impact of credit risk management on financial performance of commercial banks in Nepal. International Journal of arts and commerce, 1(5), 9-15.

[22]. Onaolapo, A. R. (2012). Analysis Of Credit Risk Management Efficiency In Nigeria Commercial Banking Sector,(2004-2009). Far East Journal of Marketing and Management, 2(4), 39-52.

[23]. Ogboi, C., \&Unuafe, O. K. (2013). Impact of credit risk management and capital adequacy on the financial performance of commercial banks in Nigeria. Journal of Emerging Issues in Economics, Finance and Banking,2(3), 703-717.

[24]. Marshal, I., \&Onyekachi, O. (2014). Credit Risk and Performance of Selected Deposit Money Banks in Nigeria: An Empirical Investigation.European Journal of Humanities and Social Sciences Vol, 31(1).

[25]. Galvao, A. F., Montes-Rojas, G., Sosa-Escudero, W., \& Wang, L. (2013). Tests for skewness and kurtosis in the one-way error component model. Journal of Multivariate Analysis, 122, 35-52. 
[26]. Roodman, D. (2006). How to do xtabond2: An introduction to difference and system GMM in Stata. Center for Global Development working paper, (103).

[27]. Arellano, M., \& Bond, S. (1991). Some tests of specification for panel data: Monte Carlo evidence and an application to employment equations. The review of economic studies, 58(2), 277-297.

[28]. Arellano, M., \&Bover, O. (1995). Another look at the instrumental variable estimation of error-components models. Journal of econometrics, 68(1), 29-51.

[29]. Blundell, R., \& Bond, S. (1998). Initial conditions and moment restrictions in dynamic panel data models. Journal of Econometrics, 87(1), 115-143.

[30]. Ruziqa, A. (2013). The impact of credit and liquidity risk on bank financial performance: the case of Indonesian Conventional Bank with total asset above 10 trillion Rupiah. International Journal of Economic Policy in Emerging Economies, 6(2), 93-106.

[31]. Felix, A. T., \& Claudine, T. N. (2008). Bank Performance and Credit Risk Management. Unpublished Masters Dissertation in Finance, University of Skovde.

[32]. Sufian, F., \&Habibullah, M. S. (2009). Bank specific and macroeconomic determinants of bank profitability: Empirical evidence from the China banking sector. Frontiers of Economics in China, 4(2), 274-291.

[33]. Duca, J. and McLaughlin, M.M. (1990). Developments affecting the profitability of Commercial banks', Federal Reserve Bulletin, 76( 7), 477- 499 